\title{
Corporate Social Responsibility in Controversial Industries or How to Fail Spectacularly
}

\author{
Davit Belkania \\ Kaposvár University, Kaposvar, Hungary
}

\begin{abstract}
The present study is a critical appraisal of corporate social responsibility (CSR) and the certain type of the industry players who manage to conceal their detrimental core businesses behind CSR façade. Accordingly, the paper explores existing controversies between theoretical understanding and practical implementation of CSR, as well as the failure of the legal framework concerning CSR reporting. The paper suggests the following as a remedy for the existing problems: denotational refinement of CSR from versatile to explicit, inclusion of constructive criticism through NGOs, the inception of common framework vis-à-vis CSR reporting, and ranking/monitoring of companies by third-party organizations.
\end{abstract}

Keywords: CSR, controversial industries, CSR reporting

\section{Introduction}

From the very beginning, corporate social responsibility (CSR) was considered as a voluntary, self-regulatory tool for the firms to monitor their legal and ethical standards, which in some cases could go beyond the interests of a firm and provide numerous social benefits for the society it serves.

Unfortunately, considering the present-day application of CSR, it definitely lost its voluntary and humane character. It is no wonder that CSR is used as a profitable, strategic tool that enables a certain firm to conceal its poor reputation and at the same time increase customer loyalty. Instead, the most fascinating fact is that companies from controversial industries are able to engage in CSR activities/reporting without any restrictions, thus hiding their harmful and environmentally unfriendly businesses behind CSR façade. Correspondingly, ugly truth about CSR is the inability and failure of third-party ranking/monitoring institutions to exclude unethical firms with detrimental core businesses from the list of truly socially responsible companies. As a result, it damages the conceptual idea behind CSR and simply transforms it into a "dirty" marketing tool.

\section{The Conceptual Background of CSR and How We Define It}

Despite the denotational dispute, many scholars agree that the idea behind CSR lays beyond the private interests of the firm. Fighting against climate change, applying environmentally friendly technologies, or delivering complimentary social benefits are the fundamental concepts of CSR. In that case, CSR should

Davit Belkania, Ph.D. candidate, Doctoral School in Management and Organizational Sciences, Kaposvár University, Kaposvar, Hungary.

Correspondence concerning this article should be addressed to Davit Belkania, Doctoral School in Management and Organizational Sciences, Kaposvar University, st. Guba Sandor 40, Kaposvar 7400, Hungary. 
incorporate voluntary character, if not, then conducting CSR is not more than a marketing tool asserted as a consistent growth engine.

Historically, CSR was defined in many ways due to its versatile nature. Here are some examples from its retrospect:

Friedman in his paper "The Social Responsibility of Business Is to Increase its profits” (1970) pointed out quite roughly:

The businessmen believe that they are defending free enterprise when they declaim that business is not concerned "merely" with profit but also with promoting desirable "social" ends; that business has a "social conscience" and takes seriously its responsibilities for providing employment, eliminating discrimination, avoiding pollution and whatever else may be the catchwords of the contemporary crop of reformers. In fact, they are—or would be if they or anyone else took them seriously — preaching pure and unadulterated socialism. Businessmen who talk this way are unwitting puppets of the intellectual forces that have been undermining the basis of a free society these past decades. (p. 1)

Moving forward to the beginning of the 21st century, scientists Crowther and Aras (2008) defined CSR as follows:

The broadest definition of corporate social responsibility is concerned with what is—or what should be the relationship between the global corporation, governments of countries and individual citizens; more locally the definition is concerned with the relationship between a corporation and the local society in which it resides or operates. (p. 10)

Coelho, McClure, and Spry (2003) said about CSR: "It can refer to the legal liability and secondly social responsibility as an ethical issue" (p. 1).

Authors partially opposed Friedman's idea about CSR and claimed that "the fiduciary duty to firms' owners, that means managers' legal obligation to act in the best interest of stakeholders, is the bedrock of capitalism, and capitalism will wither without it” (Coelho et al., 2003, p. 1).

Bloom and Gundlach (2001) in Handbook of Marketing and Society said:

CSR is the obligations of the firm to its stakeholders-people and groups who can affect or who are affected by corporate policies and practices. These obligations go beyond legal requirements and the company's duties to its shareholders. The fulfillment of these obligations is intended to minimize any harm and maximize the long run beneficial impact of the firm on society. (p. 142)

Kotler and Lee (2004) in Corporate Social Responsibility—Doing the Most Good for Your Company and Your Cause said: "CSR is a commitment to improving community well-being through discretionary business practices and contributions of corporate resources” (p. 3).

Although scientists cannot reach the consensus to provide precise definition, they all agree that CSR, whether it is conducted voluntarily or is the case of fiduciary duty towards firms' owners, will deliver a profit to both society and stakeholders; as so, delivering a profit is a social responsibility of any business enterprise (Idowu, 2012).

\section{Practical Application of CSR}

Nowadays, carrying out CSR activities is a guarantee for firms either improve or conceal their bad reputation. Apparently, the key to sustainable competitive advantage lies not on their balance sheet nor in the human capital of their workforce, rather it is their reputation (Minor \& Morgan, 2011). Hence, being a socially responsible citizen serves as an "organizational remedy" for firms to treat their socially irresponsible behavior. 
CSR is believed to enhance positive publicity, avoid negative media coverage, reduce production cost, or develop a strong base for customer relations (Sprinkle \& Maines, 2010). Some other evidence suggests that big corporations engage in CSR to stimulate positive relations with the government by this increase the chance of regulatory cost reduction (Borghesi, Houston, \& Naranjo, 2014). Exploring the topic from a managerial perspective shows that motivation behind investing in CSR activities can vary from CEOs' personal benefits to stakeholder satisfaction (Borghesi et al., 2014).

On the other hand, couple of studies provide evidence that some firms engage in CSR activities from pure altruistic perspective, e.g., Sprinkle and Maines (2010) stated that one reason explaining a firm's motivation to do CSR can be simply philanthropic, hence, providing the examples of SC Johnson, Gap Inc., and Target who claim that CSR is just the right thing to do. Besides, the authors recall Alsop (2002) which emphasized the altruistic behavior of Honda, Wal-Mart, and Procter \& Gamble that donated millions but refused to publicize it. Similarly, Dizik (2009) assumed that large donations made by Merck \& Co. in poor geographical regions is not meant to produce financial benefits, rather it represents disinterested behavior of the firm.

The aforementioned examples are truly tempting to be perceived as non-profit generating, but it is hard to ignore the existence of the corporate philanthropy and its profound financial benefits. In 21st century, it does not matter if a firm publicize or not its actions whether it is philanthropic or profit seeking. Current media coverage is boundless, meaning that literally nothing can be left unnoticed. Accordingly, firms are well aware of the situation, hence, refusing consciously to publicize their donations is simply the one way to get even more attention and bringing charity activities to a whole new level. Masking their ulterior motive by refusing to go public increases the positive perception by consumers regarding the philanthropic nature of a firm.

All the aforementioned benefits of being a socially responsible citizen do not necessarily neglect voluntary roots of CSR, but rather visualizes the difference between theoretical understanding of CSR and its practical implementation-What it should be and what it is now; roughly similar as negative effects of Viva Voce-When the main message reflected in theoretical statement is wrongly interpreted in practice.

\section{Elephant in the Room: CSR in Controversial Industries}

The main attraction of CSR is the sense of self-responsibility to protect the environment and give credence to civic duty rather than a legal obligation imposed by law. Unfortunately, many firms acknowledge CSR as a legal obligation or just a marketing tool for long-term financial benefit. Thus, the voluntary nature of CSR is slowly becoming the nostalgic allure once existed.

Nowadays, the financial benefits of conducting CSR are progressively attracting new firms. Some of them use dirty marketing tools, like greenwashing, to boost their profitability or hide their harmful and environmentally unfriendly businesses behind CSR façade. Even firms from controversial industries are shamefully engaged in the process. The most surprising fact regarding dirty industries performing CSR is that they really gain credibility and experience positive effect on firm value, although their core business is completely opposite of "doing good” (Cai, Jo, \& Pan, 2012), e.g., from 2003 when British American Tobacco (BAT) first published CSR report BAT continuously receives awards for being a "socially responsible citizen" (e.g., continuing inclusion in the Dow Jones Sustainability Indexes for nine consecutive years; ranked number two in the Financial Times and Stock Exchange [FTSE] 350 for our approach to sustainability assurance in the 2010 Carbon Smart ranking of assurance practices; placed in the top three in the 2010 PricewaterhouseCoopers' Building Public Trust Award for Sustainability Reporting in the FTSE 100). It seems that firms with 
detrimental core businesses are well aware of the fundamental attribution error (FAE) attached to post-CSR activities and using it quite deftly in their favour. In social psychology, FAE often referred to as the correspondence bias, is the concept reflecting the tendency to believe that what people do reflects who they are (Bicchieri, 2017). ${ }^{1}$ Hence, we can ignore the role of the external factors in the judgment. In this regard, the firms from dirty industries are persistent on doing good through the CSR activities, by these increasing the chances to be perceived as socially responsible actors.

On the other hand, another set of evidence suggests that people often suspect positive behaviour of the bad actors, thus, engaging in more sophisticated attributional reasoning which in some cases triggers CSR activities to be rendered as ineffective with a possibility to backfire (Yeosun \& Norbert, 2006). However, despite those "fancy" explanations/reasoning regarding social behaviour, objectivity/rationality of the consumers/economic actors, etc., what we all see is the flourishing businesses from controversial industries whose engagement in CSR activities is skyrocketing leaving them with cleaner reputation, increased customer loyalty, and financial prosperity, e.g., Minor and Morgan (2011) was the perfect illustration of how engagement in CSR activities can ensure a firm's positive publicity; the authors addressed the question through the application of the case study and the multi-year analysis of stock price responses for S\&P 500 companies following product recalls. The study found that the firms with strong CSR background performed way better than those who do not. Acknowledging the positive outcome from doing CSR, firms from dirty industries invest sizable amount of resources to keep their reputation on track.

The problem is real, but few want to address it. Apparently, governments, as well as CSR monitoring agencies are eager to tip these firms with different awards with respect to CSR policies. Fortunately, there are multiple evidences of particular society/NGOs resisting this insanity. For instance,

In Hungary, BAT became the center of attention of health advocates when it announced its substantial strengthening of the sponsorship of the University of Pecs that made it the principal sponsor of the second largest university of the country...Western Michigan University was heavily criticized by Campaign for Tobacco-Free Kids for its decision to honor Philip Morris USA Inc. as its employer of the year. (Palazzo \& Richter, 2005, p. 391)

Examples are even more in countries with sufficient CSR awareness. This controversial attitude between officials/firms and society stimulates positive influence on CSR monitoring/ranking agencies and strive them to exclude "bad organizations" from their lists. As Hirschhorn (2004) once said, "it is essential to caution the public against uncritical acceptance of the tobacco industry’s mantle of "social responsibility".

\section{CSR Reporting: Does It Really Matter?}

Although there is no precise definition of CSR reporting, it can be referred as an organizational report incorporating the firm's values, goals, financial facts, strategy, and commitment to civic duty that can assist to acknowledge the financial, environmental, and social performance of a firm. These reports are extremely flexible and come in various shapes and forms, but the goal is to reflect the relationship between firms and society (How to read CSR Report 2010). Every single firm is free to create its own "story" in its own way. However, the flexible nature of CSR reports is not always convenient and comes with a number of drawbacks, for instance, length of the report, deadline (monthly, quarterly, yearly, etc.), unreliable data, completely internal

\footnotetext{
${ }^{1}$ Online lecture series on Social Norms, Social Change II by Cristina Bicchieri. https://www.coursera.org/lecture/change/9-5-3m $1 \mathrm{nZ}$
} 
evaluation (lack of external monitoring), absence of common standards (e.g., Global Reporting Initiative), etc. Thus, it transforms CSR reporting into an unreliable document that lost its essence. Most importantly, this high degree of freedom encourages firms from dirty industries to use CSR reporting as a shield to mask their detrimental businesses. Therefore, publishing CSR reports is not an apriori that a firm is socially accountable.

\section{Final Notes}

This work is not judging whether CSR is good or bad, contrary it argues in which aspect it failed. One can doubt that it is not CSR who failed, rather the company measuring it; but it simply does not reflect the truth, since all these monitoring agencies, measuring indices, legal obligations, or CSR reporting standards are created by CSR advocates that help us to evaluate the performance of the firms. The problem itself is the boundless flexibility of the concept of CSR and the absence of the framework that would forbid firms from controversial industries to be identified as "socially responsible citizens". Therefore, in its pure nature, it is the fault of CSR to empower "bad" companies with inappropriate core businesses to conceal their inferior reputation and increase profitability. This is how it works in practice: Profitability of a company highly depends on brand/customer loyalty (Melnyk \& Bijmolt, 2015) which is influenced by the reputation of a firm (Gotsi \& Wilson, 2001). At this point, reputation can be perfectly managed through CSR activities (Maden, Arikan, Telci, \& Kantur, 2012), which is a guarantee for firms either improve or conceal their bad publicity. If we succeed to forbid evaluation/ranking of the "dirty firms", and raise the awareness of detrimental core businesses, CSR can negatively affect the profitability of those firms; but in reality, these firms are the high taxpayers that fuel the economies, so it is even favorable for governments to have them. Thus, we voluntarily agree to harm us and make them pay at least something that can benefit society. From this perspective, CSR encourages sales growth of firms from dirty industries, so it helps (directly or indirectly) to kill more. In this case, growth achieved by "dirty firms" through CSR engagement can be seen as a negative externality. Hence, it is our duty as the ethical, socially responsible citizens to raise the voice against this unfair game.

After all, it seems to be evident that the solution to the aforementioned problems cannot be achieved without the following:

- Denotational refinement of CSR from versatile to explicit;

- Inclusion of constructive criticism through NGOs;

- The inception of common framework vis-à-vis CSR reporting and ranking/monitoring of companies by third-party organizations.

\section{References}

Alsop, R. (2002). Perils of corporate philanthropy: Touting good works offends the public, but reticence is perceived as inaction. The Wall Street Journal, p. B1.

Bloom, P. N., \& Gundlach, G. T. (2001). Handbook of marketing and society. London, UK: SAGE Publishing.

Borghesi, R., Houston, J. F., \& Naranjo, A. (2014). Corporate socially responsible investments: CEO altruism, reputation, and shareholder interests. Journal of Corporate Finance, 26(C), 164-181.

Cai, Y., Jo, H., \& Pan, C. (2012). Doing well while doing bad? CSR in controversial industry sectors. Journal of Business Ethics, Springer, 108(4), 467-480.

Coelho, P. R. P., McClure, J. E., \& Spry, J. A. (2003). The social responsibility of corporate management: A classical critique. American Journal of Business, 18(1), 15-24.

Crowther, D., \& Aras, G. (2008). Corporate social responsibility. Frederiksberg, Denmark: Ventus Publishing.

Dizik, A. (2009, November 19). Education for executives: Teaching the golden rules. The Wall Street Journal, p. B8. 
Friedman, M. (1970). The social responsibility of business is to increase its profits. The New York Times Magazine, September 13 1970. Retrieved from http://umich.edu/ thecore/doc/Friedman.pdf

Gotsi, M., \& Wilson, A. M. (2001). Corporate reputation management: Living the brand. Management Decision, 39(2), 99-104.

Hirschhorn, N. (2004). Corporate social responsibility and the tobacco industry: Hope or hype? Tobacco Control, 13(4), 447-453.

Idowu, S. O. (2012). Corporate social responsibility: A capitalist ideology? International Journal of Entrepreneurship and Innovation Management, 1(3), 239-254.

Kotler, P., \& Lee, N. (2004). Corporate social responsibility—Doing the most good for your company and your cause. New Jersey, USA: John Wiley \& Sons Inc.

Maden, C., Arikan, E., Telci, E. E., \& Kantur, D. (2012). Linking corporate social responsibility to corporate reputation: A study on understanding behavioral consequences. Procedia-Social and Behavioral Sciences, 58, 655-664.

Melnyk, V., \& Bijmolt, T. (2015). The effects of introducing and terminating loyalty programs. European Journal of Marketing, 49(3), 398-419.

Minor, D. B., \& Morgan, J. (2011). CSR as reputation insurance: Primum Non Nocere. California Management Review, 53(3), 40-59.

Palazzo, G., \& Richter, U. (2005). CSR business as usual? The case of the tobacco industry. Journal of Business Ethics, 61(4), 387-401.

Sprinkle, G. B., \& Maines, L. A. (2010). The benefits and costs of corporate social responsibility. Business Horizons, 53(5), 445-453.

Yeosun, Y., \& Norbert, S. (2006). The effect of corporate social responsibility (CSR) activities on companies with bad reputations. Journal of Consumer Psychology, 16(4), 377-390. 